\title{
Eyelid necrotic loxoscelism and reconstruction with cutaneous autograft. $A$ case report
}

\section{Loxoscelismo necrótico palpebral y reconstrucción con autoinjerto cutáneo. Reporte de un caso}

\author{
Juliana M. Morales-Avalos ${ }^{*}$, Adolfo J. Torres-Moreno ${ }^{2}$, Román Zamora-Gómez ${ }^{3}$, and \\ Hiram J. Arce-Sánchez ${ }^{3}$ \\ ${ }^{1}$ Servicio de Oftalmología Oculoplástica; ${ }^{2}$ Servicio de Oftalmología del Segmento Anterior; ${ }^{3}$ Servicio de Infectología. Hospital General de Culiacán, \\ Culiacán, Sinaloa, Mexico
}

\begin{abstract}
Poisonous spider bites are common in our territory due to their presence throughout the country, and the two most common species are the violin or brown recluse spider (Loxosceles reclusae) and the capulin or black widow spider (Latrodectus mactans). They are considered poisonous because they inoculate toxic substances that injure the tissues after a bite, causing pathophysiological alterations of variable severity. Necrosis is characteristic of a loxosceles bite, known as loxoscelism. We present the case of a 56-year-old male with no relevant history. He developed an inflammatory condition that involved the upper eyelid and the superior extraconal orbital region. Its evolution to necrosis required tissue debridation and reconstruction with a full-thickness cutaneous autograft from the contralateral upper eyelid, with a satisfactory evolution.
\end{abstract}

Key words: Bite of poisonous spider. Loxoscelism. Eyelid necrotic loxoscelism. Skin autograft. Eyelid reconstruction.

\section{Resumen}

En nuestro medio son frecuentes las mordeduras por arañas venenosas debido a que su presencia abarca la mayor parte del país. Las dos especies más comunes son la araña violinista o parda (Loxosceles reclusae) y la araña capulina o viuda negra (Latrodectus mactans). Se consideran venenosas porque provocan una lesión cutánea por la mordedura, seguida de la inoculación de sustancias tóxicas que lesionan los tejidos, condicionando alteraciones fisiopatológicas de gravedad variable. La necrosis es característica de la mordedura por loxosceles, conocida como loxoscelismo. Presentamos el caso de un paciente de 56 años, sin antecedentes patológicos sistémicos, que desarrolló un cuadro inflamatorio que involucró el párpado superior a la región orbitaria extraconal superior. Su evolución a la necrosis requirió debridación de tejidos y reconstrucción con autoinjerto cutáneo de espesor completo del párpado superior contralateral, con una evolución satisfactoria.

Palabras clave: Mordedura de araña venenosa. Loxoscelismo. Loxoscelismo necrótico palpebral. Autoinjerto cutáneo. Reconstrucción palpebral.

\section{Correspondence:}

*Juliana M. Morales-Avalos

Río Culiacán 102 ote

Col. Guadalupe

Fecha de recepción: 24-07-2020

Fecha de aceptación: 26-11-2020

C.P. 80220, Culiacán, Sin., Mexico

E-mail: marzzela@ hotmail.com
Available online: 13-04-2021 Rev Mex Oftalmol (Eng). (ahead of print) www.rmo.com.mx 2604-1731/@ 2020 Sociedad Mexicana de Oftalmología. Published by Permanyer. This is an open access article under the CC BY-NC-ND license (http://creativecommons.org/licenses/by-nc-nd/4.0/). 


\section{Introduction}

The patient had a rapid onset of left upper eyelid swelling of unknown etiology. On interrogation, he disclosed observing brown spiders in his home.

For this study, we performed a review of the bites by Loxosceles reclusae (violin or brown recluse spider), characterized by the development of vasculitis associated with necrosis, common in our territory.

Loxesceles are small, they measure from 9 to $25 \mathrm{~mm}$, they are common in Northwest Mexico, they can live in temperatures of 8 to 40 , are brown and they have a dark mark that resembles a violin on the dorsal side of the cephalothorax. They have nocturnal habits and are found in sparsely traveled spaces, behind or under little-used objects ${ }^{1,2}$.

The clinical picture of the violin or brown recluse bite (loxoscelism) is produced by the inoculation of its venom containing various enzymes, of which sphingomyelinase $D$ is responsible for necrosis and hemolysis, producing an inflammatory reaction mediated by arachidonic acid and prostaglandins that causes vasculitis ${ }^{3-5}$. Clinical presentation may be cutaneous or systemic, and the intensity of the reaction depends on the amount of venom inoculated and in the person's susceptibility to the compounds ${ }^{6,7}$. The cutaneous clinical presentation is the most common in $80 \%$ of the cases. It includes edema, erythema and ischemia that tends to evolve to ulceration and deep but localized necrosis ${ }^{8}$. Complete blood count shows leukocytosis with neutrophilia. Cutaneous-visceral loxoscelism is more serious, since it involves a systemic reaction associated with disseminated intravascular coagulation, renal failure and liver damage within 24 hours after the bite ${ }^{9}$, accompanied by anemia with reticulocytosis, thrombocytopenia, increased indirect bilirubin, decreased haptoglobin ${ }^{10}$, hyperkalemia, increased creatinine, uremia, coagulation disorders and hemoglobinuria ${ }^{11}$.

\section{Case report}

A 53-year-old male with no history of systemic disease came to our institution and reported the onset of his condition 4 days before admission, with increased left upper eyelid volume, pruritus, erythema and honey-colored crusts with apparent pretarsal puncture wounds on the middle third (Fig. 1).

The patient could not open the eyelid so we requested a computerized axial tomography, that revealed the presence of a hyperdense material in the entire eyelid directed to the superior extraconal sector of the orbit (Fig. 2).

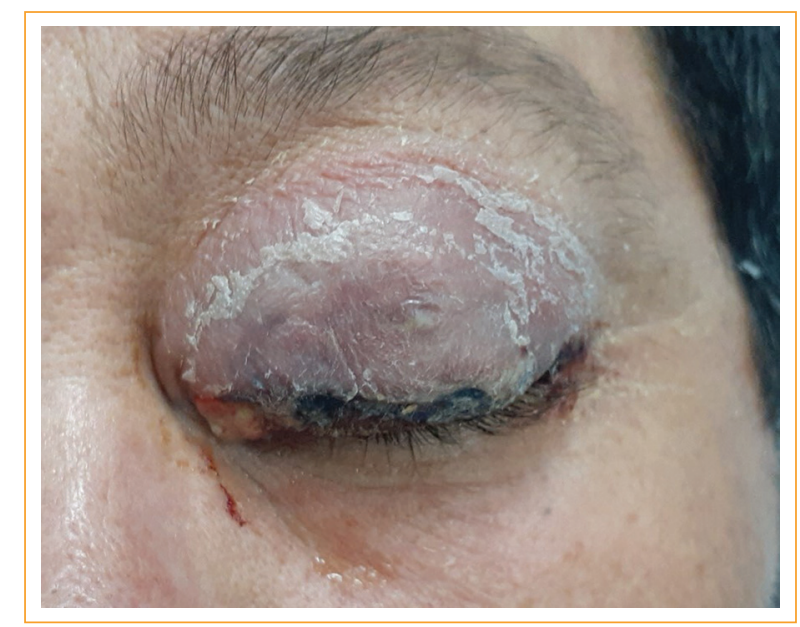

Figure 1. Cellulitis of the left upper eyelid. Third day of hospitalization.

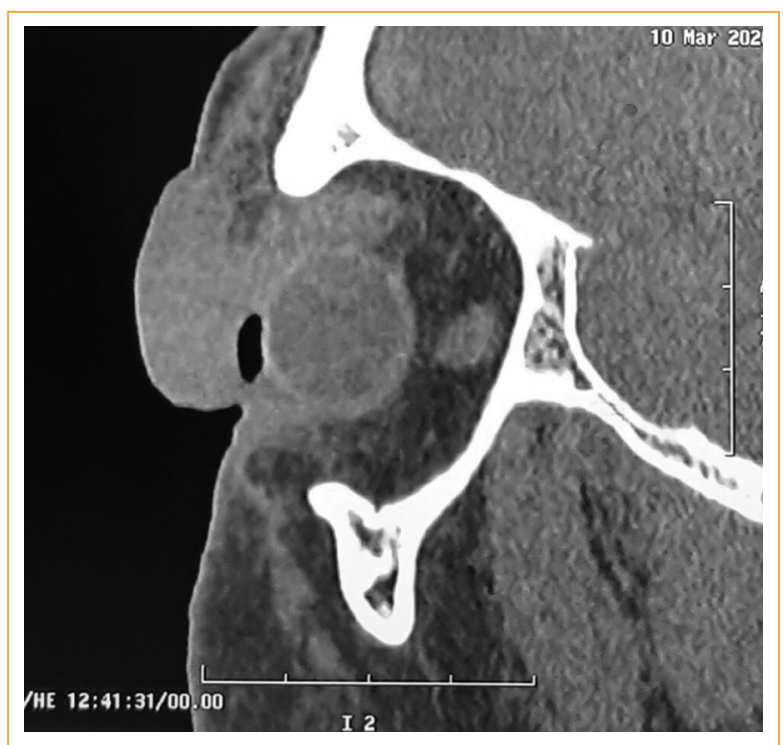

Figure 2. Sagittal CT of the left orbit, showing a hyperdense content in the entire eyelid and extraconal upper sector.

Upon admission, Department of Infectious Diseases indicated ceftriaxone, vancomycin and intravenous dexamethasone. Complete blood count showed the following values: hemoglobin $15.9 \mathrm{~g} / \mathrm{L}$, leukocytes $14.60 \times 109$ / L, neutrophils $72.8 \times 109$ / L. We performed drainage of the eyelid abscess with exploration and debridement of preseptal necrotic tissue, followed by daily wound care; the cultures of the purulent material showed no growth. When the ocular evaluation was possible, visual acuity and extraocular muscle function were normal. Later, the 


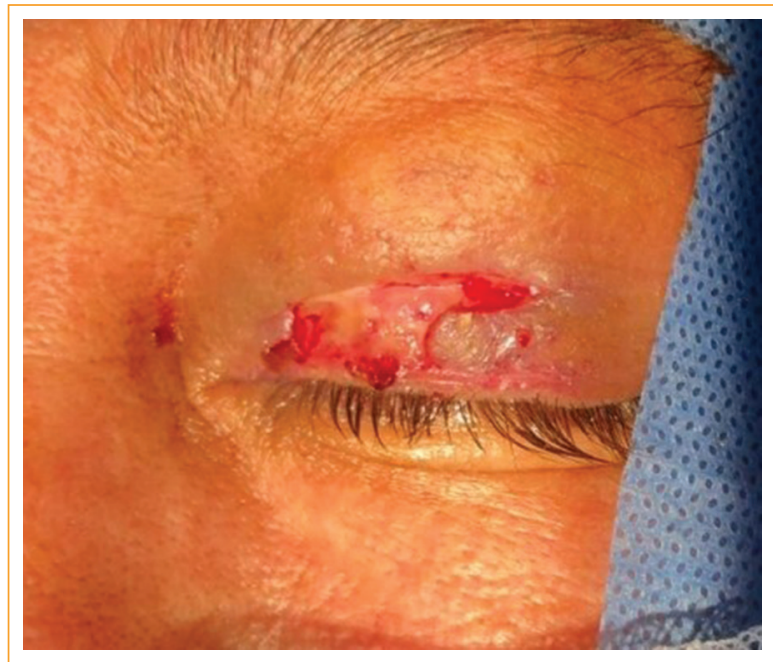

Figure 3. Debridement of necrotic tissue and wound edges.

patient developed necrosis of the cutaneous tissue in the inner and middle third of the pretarsal and preseptal areas of the eyelid; 7 days later, in a second surgical procedure, confirming the absence of active necrosis and purulent material, we performed debridement and refreshed the wound edges (Fig. 3) to place a full-thickness skin graft that included orbicular fibers, taking the donor area from the contralateral upper eyelid by blepharoplasty. The evolution of the patient was favorable, with integration of the skin graft without complications (Fig. 4).

\section{Discussion}

We consider important to present this case since it is a public health issue. There are between three thousand and five thousand cases of spider bites reported per year in our country, from which $1.7 \%$ occur on the face, and due to the severity of these cases, we must be aware and initiate timely treatment in conjunction with the epidemiology and Department of Infectious Diseases. The cases of loxoscelism are those associated with the development of tissue necrosis caused by vasculitis. The identification of the spider is achieved in less than $5 \%$ of the cases; therefore, it is recommended to treat the patients in the hospital for monitoring and administration of broad-spectrum antibiotics and intravenous anti-inflammatory drugs. An ELISA immunological test can detect the circulating venom; however, it is not done routinely, so diagnosis is based

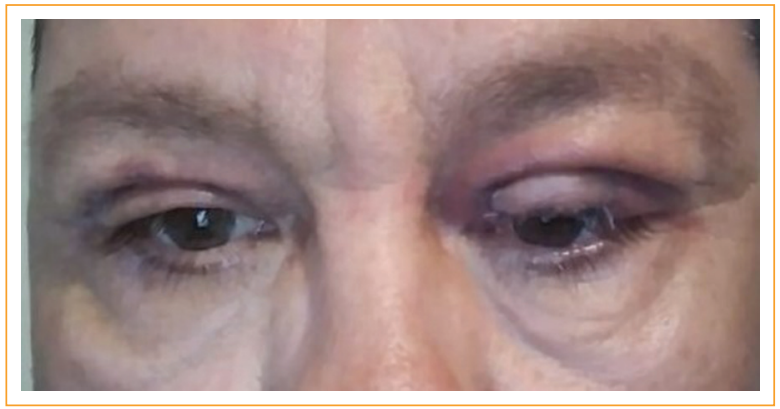

Figure 4. Ten days after the placement of a full-thickness skin autograft taken from the contralateral eyelid.

on the clinical presentation. In the literature, there are few described cases of necrotic arachnidism of the eyelid, and only one reported the need for reconstruction using a full-thickness skin graft taken from the retro auricular region in a young patient. In our patient, with a $40 \%$ defect in the skin surface of the upper eyelid, we decided to perform the reconstruction with a full-thickness skin graft taken from the contralateral upper eyelid using blepharoplasty for a better cosmetic result.

\section{Conclusion}

It is necessary to keep this condition in mind, to exclude other diagnosis such as bacterial infections, gangrenous ecthyma; viral infection: herpes simplex or zoster; fungal infections; occlusive vascular venous disease such as necrotizing vasculitis; chemical, thermal or traumatic injuries, including Stevens Johnson's and toxic epidermal necrolysis, for which we must carry out a detailed medical history. The clinical presentation after a poisonous spider bite can be of variable severity, so we must keep the patient under close monitoring, alerting them to be aware about the development of systemic signs and symptoms and proceed according to established protocols.

\section{Funding}

The authors received no funding for this work.

\section{Conflicts of interest}

The authors declare that they have no conflicts of interest. 


\section{Ethical disclosures}

Protection of human and animal subjects. The authors declare that no experiments were performed on humans or animals for this study.

Confidentiality of data. The authors declare that they have followed the protocols of their work center on the publication of patient data.

Right to privacy and informed consent. The authors have obtained the written informed consent of the patients or subjects mentioned in the article. The corresponding author is in possession of this document.

\section{References}

1. Consejo de Salubridad General. Guía de referencia rápida, diagnóstico y tratamiento de mordeduras por arañas venenosas. México. Reg.: SSA- 523-11.
2. Zúñiga IR, Caro J. Aspectos clínicos y epidemiológicos de las mordeduras de araña en México. Hosp Med Clin Manag. 2018;11:191-203.

3. Ribuffo D, Serratore F, Famiglietti M, Greco M, Fois F, Atzori L, et al. Upper eyelid necrosis and reconstruction after spider bite: case report and review of the literature. Eur Rev Med Pharmacol Sci. 2012;16:414-7.

4. Baijin MS, Arikan G, Parlak M, Tuncok Y, Yigit N, Durak I, et al. Necrotic arachnidism of the eyelid due to Loxosceles rufescens spider bite. Cutan Ocul Toxicol. 2011;30:302-5.

5. Bilgili SG, Karadag AS, Karadag R, Cecen I, Calka O. A case of spider bite localized to the eyelid. Cutan Ocul Toxicol. 2013;32:83-5.

6. Jarvis RM, Neufeld MV, Twestfall C. Brown recluse spider bite to the eyelid. Ophthalmology. 2000;107:1492-6.

7. Cole HP, Wesley RE, King LE. Brown recluse spider envenomation of the eyelid: an animal model. Ophth Plast Reconstr Surg. 1995;11:153-64.

8. Keklikci U, Akdeniz S, Sakalar YB, Cakmak SS, Unlu K. Loxosceles reclusa bite to the eyelid. Eur J Ophthalmol. 2008;18:633-5.

9. Tay Zavala J, Díaz Sánchez JG, Sánchez Vega JT, Castillo Alarcón L, Ruiz Sánchez D, Calderón Romero L. Picaduras por alacranes y arañas ponzoñosas de México. Rev Fac Med UNAM. 2004;47:6-12.

10. Sistema Nacional de Vigilancia Epidemiológica. Boletín Epidemiológico. México. 2016;33:1-8.

11. Sánchez Olivas MA, Valencia Zavala MP, Sánchez-Olivas JA, Sepúlveda-Velázquez G, Vega-Robledo G. Loxoscelismo cutáneo necrótico. Informe de un caso. Revista Alergia México. 2011;58:171-6. 